\title{
Research
}

\section{The correlation of MMP-9 and VEGF expressions towards nasopharyngeal angiofibroma clinical stage}

\author{
Yuli Tetriana Sari*, Rizalina Asnir*, Ashri Yudhistira*, Izry Naomi Lumbantobing** \\ *Department of Otorhinolaryngology - Head and Neck Surgery \\ Faculty of Medicine Universitas Sumatera Utara/Haji Adam Malik Hospital, Medan \\ **dr. Hadrianus Sinaga Regional Hospital, Samosir
}

\begin{abstract}
Background: Nasopharyngeal angiofibroma (NA) is a benign tumor with a destructive tendency, commonly affecting male adolescents. The management of NA could become quite a challenge because it is highly vascularized, and localized in an intricate area. Recently, the role of molecular biology in the development of NA is the research target for a better prognosis. Purpose: To analyze the correlation between expressions of matrix metalloproteinase (MMP-9) and vascular endothelial growth factor (VEGF) with clinical stage, and the correlation between these two markers and nasopharyngeal angiofibroma. Method: This was a descriptive analytic study using cross sectional method. Twenty-four postoperative NA cases were categorized into early and advance stages according to Chandler classification. Evaluation of MMP-9 and VEGF expressions were examined by immunohistochemistry. The correlation of VEGF and MMP-9 towards clinical stage, was analyzed using chi-square or Fisher's exact test $(\alpha=0.05)$. Result: No significant correlation between MMP-9 expression and clinical stage $(p=0.204)$, whereas VEGF expressions and clinical-stage showed a significant correlation $(p<0.001)$. Statistical analysis on correlation between MMP-9 and VEGF expressions showed no significant result $(p=0.099)$. Discussion: MMP-9 produces pro-angiogenic and anti-angiogenic factors. MMP-9 expression does not affect the growth of NA. VEGF is a pro-angiogenic growth factor that has the most important role in tumor pathophysiology and induces vasculogenesis and angiogenesis. VEGF secretion is affected by pro-angiogenic and antiangiogenic activities of MMP-9. Conclusion: VEGF expression is related to the clinical stage of NA. Anti-VEGF could be further investigated as an alternative treatment for NA.
\end{abstract}

Keywords: MMP-9, VEGF, nasopharyngeal angiofibroma, clinical stage

\section{ABSTRAK}

Latar belakang: Angiofibroma nasofaring (AN) merupakan suatu tumor jinak dengan kecenderungan destruktif. Penatalaksanaan AN merupakan tantangan karena banyaknya vaskularisasi, anatomi yang kompleks dan terjadi pada usia muda. Peranan biologi molekular pada pertumbuhan AN menjadi sasaran penelitian untuk mencari prognosis yang lebih baik. Tujuan: Mengetahui hubungan ekspresi matrix metalloproteinase-9 (MMP-9) dan vascular endothelial growth factor (VEGF) dengan stadium klinis, dan hubungan kedua marker tersebut pada AN. Metode: Studi analitik deskriptif menggunakan metode potong lintang. Dua puluh empat kasus AN pasca operasi, ditentukan stadiumnya berdasarkan klasifikasi Chandler, dan dikelompokkan menjadi kategori awal dan lanjut. Evaluasi ekspresi VEGF dan MMP-9 diperiksa secara immunohistokimia. Korelasi VEGF dan MMP-9 terhadap stadium klinis dianalisis menggunakan Chi-square atau Fisher's exact test $(\alpha=0.05)$. Hasil: Tidak terdapat hubungan yang bermakna antara ekspresi MMP-9 terhadap stadium klinis $(p=0,204)$, sebaliknya ekspresi VEGF terhadap stadium klinis menunjukkan hubungan yang bermakna $(p<0,001)$. Analisis statistik antara hubungan MMP-9 dan VEGF menunjukkan hasil tidak bermakna $(p=0,099)$. Diskusi: MMP-9 memiliki kemampuan menghasilkan faktor-faktor pro-angiogenik, dan anti-angiogenik, sehingga ekspresi MMP-9 tidak mempengaruhi pertumbuhan angiofibroma nasofaring. VEGF merupakan pro-angiogenic growth factor yang memiliki peranan paling penting dalam patofisiologi tumor dan menginduksi vaskulogenesis dan angiogenesis. Sekresi VEGF dipengaruhi oleh kemampuan pro-angiogenik dan anti-angiogenik 
dari MMP-9. Kesimpulan: Ekspresi VEGF berhubungan dengan stadium klinis AN. Anti-VEGF dapat diteliti lebih lanjut sebagai alternatif pengobatan pada AN.

Kata kunci: MMP-9, VEGF, angiofibroma nasofaring stadium klinis

Correspondence address: Izry Naomi Lumbantobing, Dr. Hadrianus Sinaga Regional Hospital, Samosir. Jl. Dr. Hadrianus Sinaga Pangururan, Pintu Sona, Medan, Kabupaten Samosir, Sumatera Utara. Email: izrynaomi@gmail.com

\section{INTRODUCTION}

Nasopharyngeal angiofibroma (NA) is a non-encapsulated and highly vascular benign tumor of the nasopharynx. This tumor is rare, only less than $0.5 \%$ of all Head and Neck Carcinoma (HNC), commonly occurring in adolescent males. ${ }^{2}$ The possible site of origin is the pterygoid canal, and the tumor growth will invade the sphenopalatine foramen, sphenoid sinus and pterygopalatine fossa, and then into adjacent structures through those three sites. ${ }^{1}$

Histologically, NA is a benign tumor with a destructive tendency due to its aggressive expansion which causes bone erosion. From the nasopharynx, NA spreads into the nasal cavity, paranasal sinuses, pterygopalatine fossa, infratemporalis fossa, and in severe cases extends into the intracranial region. The management of nasopharyngeal angiofibroma is quite a challenge because it is highly vascularized, and localized within intricate area of the nasopharynx and skull-base, and affects relatively young male population. Minimally invasive surgery has a high recurrence rate, while extensive external approach may result in facial bone growth disturbance in young patients, and functional and esthetic complications. Despite its rarity, the management of NA has dramatically evolved during the last decades, mainly due to the advancement of endoscopic approaches and preoperative embolization techniques. ${ }^{2}$

Matrix metalloproteinases (MMPs) is a zinc dependent protease group which has an important role in tumor development, invasion, angiogenesis and metastasis. MMP-9 is one of MMPs with the strongest expression in NA, and is able to release vascular endothelial growth factor (VEGF) as the main promotor of angiogenesis. MMPs with collagenase activity have not yet been studied in Juvenile Angiofibroma (JNA), a unique fibrovascular tumor with prominent collagen expression. These MMPs are assumed to be involved in tumor pathology with an influence on tumor growth and angiogenesis. $^{3}$

Lately, many researches focus on biomolecular therapy which is expected to minimize the risk of complication, to enable intervention measures for inoperable cases, and can be used as palliative treatment. The role of biomolecule in the development and growth process of nasopharyngeal angiofibroma has become the mainstream research target for a better prognosis. ${ }^{4}$

The purpose of this research is to analyze the correlation between expressions of matrix metalloproteinase-9 (MMP-9) and vascular endothelial growth factor (VEGF) with clinical stage, and the correlation between these two markers with nasopharyngeal angiofibroma. The outcome of this study was expected could be used to predict the prognosis of the disease and as a basic clinical treatment for NA.

\section{METHOD}

This was a descriptive analytic study using cross sectional method, studying 24 NA 
postoperative patients at the Department of ORL-HNS, Faculty of Medicine Universitas Sumatera Utara/Haji Adam Malik Hospital, Medan from December 2018 to May 2019. Tumor stage was based on Chandler classification, and from computed tomography (CT) scan, the subjects were grouped into 2 categories: stage 1 and 2 as the early stage, and stage 3 and 4 as the advanced stage.

The evaluation of MMP-9 and VEGF were determined immunohistochemically. After deparaffinizing process, an endogen peroxidase blocking was performed using $\mathrm{H} 2 \mathrm{O} 20.5 \%$ in methanol for 30 minutes. Tris EDTA was given as pretreatment in a microwave and cooled down for 45 minutes. The MMP-9 specimen was incubated with mouse antihuman monoclonal antibodies (mAbs), and the VEGF was incubated with rabbit polyclonal antibody for one night in $4^{\circ} \mathrm{C}$ temperature. Incubation with Envision for 30 minutes and products were stained with diaminobenzidine (DAB) solution for 5 minutes and dyed with hematoxylin. The specimens were read by two anatomical pathologists at Anatomical Pathology Laboratory of Haji Adam Malik hospital to avoid bias.

The MMP-9 and VEGF overexpression were assessed by the specific brown stain on cell cytoplasm. Each score of the width and the intensity of MMP-9 and VEGF were summed up to obtain immunoreactive score. Width score was 0 if no brown cytoplasm was found, while score 1, 2 and 3, meant the brown cell cytoplasm was found $<10 \%, 10-50 \%$ and $>50 \%$ respectively. Intensity score was 0 if negative, or no brown colored on cytoplasm. Intensity score 1 if the intensity was weak or pale brown; intensity score 2 if the intensity was moderate or brown; and score 3 if the intensity was strong or dark brown. Both VEGF and MMP-9 were considered not overexpression if immunoreactive score was $0-3$, and overexpression if immunoreactive score achieved 4-6.

All data obtained were processed using IBM program Statistical Package for Social Sciences (SPSS) version 23.0. To analyze the correlation of VEGF and MMP-9 towards clinical stage, the researchers used chi-square or Fisher's exact test where $\alpha=0.05(\mathrm{Cl} 95 \%)$.

\section{RESULT}

This study involved 24 subjects of postoperative NA patients. The general characteristics were shown at Table 1. The highest age range was 15-18 years old, almost all males. Advanced stage was the most often found. MMP-9 overexpression was found on 16 samples, while VEGF overexpression on 15 samples.

Table 1. Patient's characteristics

\begin{tabular}{llcc}
\hline \multicolumn{2}{c}{ Characteristics } & Frequency & $(\%)$ \\
\hline Number of patients & 24 & 100 \\
\hline Age & $<15$ & 2 & 8.3 \\
& $15-18$ & 15 & 62.5 \\
& $19-22$ & 7 & 29.2 \\
\hline Gender & Male & & 95.8 \\
& Female & 23 & 4.2 \\
\hline Clinical stage & Stadium I-II & 1 & 41.7 \\
& Stadium III-IV & 10 & 58.3 \\
\hline MMP-9 & Overexpression & 14 & 66.7 \\
& Not overexpression & 16 & 33.3 \\
\hline VEGF & Overexpression & 8 & 62.5 \\
& Not overexpression & 15 & 37.5 \\
\hline
\end{tabular}


Overexpression of MMP-9 was found higher in advanced stage category $(78.6 \%)$, but the statistical analysis showed no significant correlation with clinical stage $(p=0.0204)$.
Overexpression of VEGF was also found higher in advanced stage category (92.9\%), and showed a significant correlation with clinical stage $(\mathrm{p}<0.001)$ (Table 2$)$.

Table 2. The correlation of MMP-9 and VEGF expression towards nasopharyngeal angiofibroma clinical stage

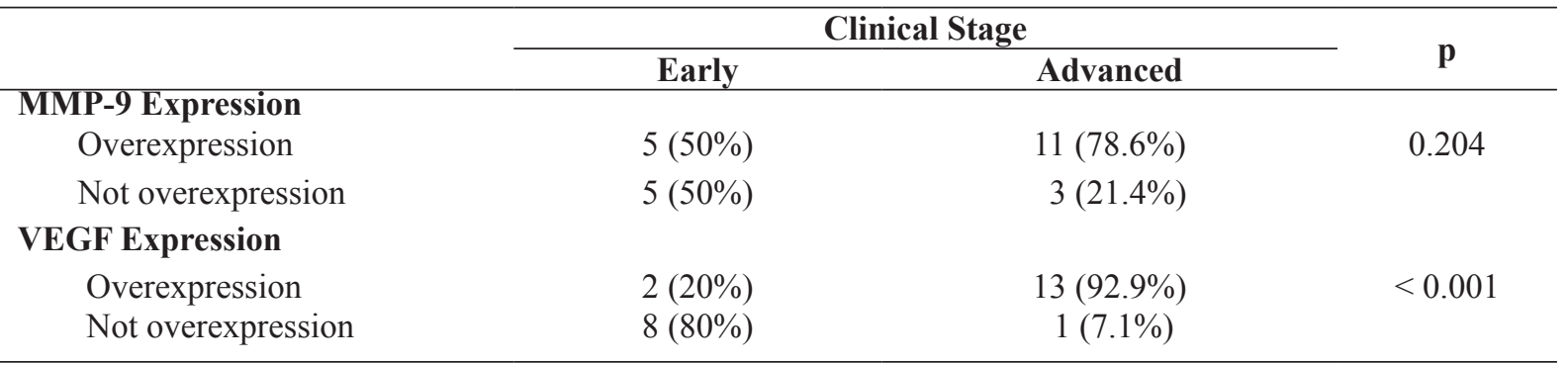

Table 3. The correlation of MMP-9 and VEGF expressions

\begin{tabular}{cccc}
\hline & \multicolumn{2}{c}{ MMP-9 Expression } & \multirow{2}{*}{$\mathbf{p}$} \\
\cline { 2 - 3 } VEGF Expression & Overexpression & Not overexpression & \\
Overexpression & $12(50 \%)$ & $3(12.5 \%)$ & $<0.099$ \\
Not overexpression & $4(16.7 \%)$ & $5(20.8 \%)$ & \\
\hline
\end{tabular}

The statistical analysis revealed that the correlation of MMP-9 and VEGF was not significant $(p=0.099)$.

\section{DISCUSSION}

The mainstay of NA treatment is surgery, although recurrence could be as high as $42 \%$, and the most often complication is bleeding. ${ }^{4}$

More researches were performed to know further about the development of this tumor in order to seek better management. MMP-9 and VEGF are biomolecules involved and have important role in tumor invasion and angiogenesis. ${ }^{3-5} \mathrm{~A}$ number of studies have indicated associations between certain biomolecules and NA. However, molecular targeting has not yet been applied in NA clinical treatment. ${ }^{4}$

This study aimed to show the involvement of MMP-9 and VEGF in NA development.

In Figure 1, MMP-9 overexpression was shown in 16 out of 24 (66.7\%) NA cases-
(Table 1). Although MMP-9 overexpression tended to be higher in advanced stage, the statistical analysis revealed that there was no significant correlation between MMP-9 expression and clinical stage $(\mathrm{p}=0.204)$ (Table 2). Studies of MMP-9 expression on NA were still limited. ${ }^{3,6}$ Sun et al. ${ }^{6}$ discovered a more significant MMP-9 expression in NA specimen compared with a normal concha media specimen $(p<0.05)$.

Similar with the finding in this study, MMP-9 expression was also reported not correlated with the clinical stage. ${ }^{6}$ It could also caused by the small number of samples which hindered analyzing each clinical stage. Beside the small sample number, MMP-9 was able to degrade extracellular matrix molecules important for tumor cell migration and invasion, MMP-9 was also able to break non-matrix substrate which produced angiogenic and anti-angiogenic factors, so that MMP-9 expression did not influence tumor development. 
Some endogen angiogenesis inhibitor mediated by MMP-9 are angiostatin, endostatin, and tumstatin. ${ }^{7,8}$ How far MMP-9 overexpression affects pro-angiogenic as well as anti-angiogenic factors, and its role towards the NA clinical stage, needs to be investigated through further studies.

In this study, the result of VEGF examination was overexpression (Figure 2 ) in 15 out of 24 cases $(62.5 \%)$ (Table 1$)$. Vascular endothelial growth factor (VEGF) had a significant correlation with the clinical stage $(\mathrm{p}<0.001)$ (Table 2$)$.

Many studies had reported the escalation of VEGF expression in NA. ${ }^{9-11}$ In line with

\section{Overexpression}

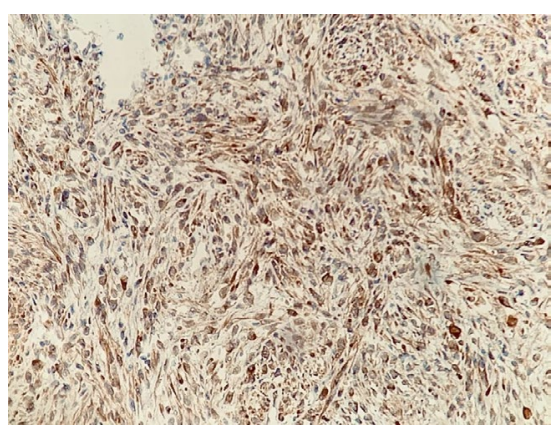

VEGF

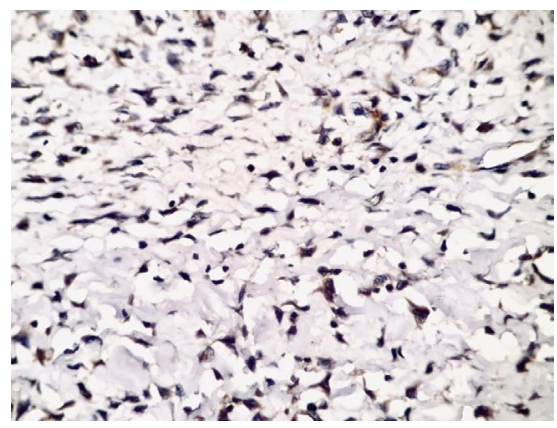

this study, Liu et al. ${ }^{12}$ reported that the escalation of VEGF expression in NA was correlated with advanced clinical stage. Hota et al. ${ }^{13}$ reported a different finding, VEGF expression had no significant correlation with clinical stage of NA.

As a pro-angiogenic growth factor which has a prominent role in tumor biology, VEGF could induce vasculogenesis and angiogenesis. This was the reason why VEGF has a correlation with the increase of proliferation and the density of blood vessel. ${ }^{12}$ However, some other opinions stated that proangiogenic factor in benign tumors has more effects towards blood vessel growth compared to tumor growth. ${ }^{10}$
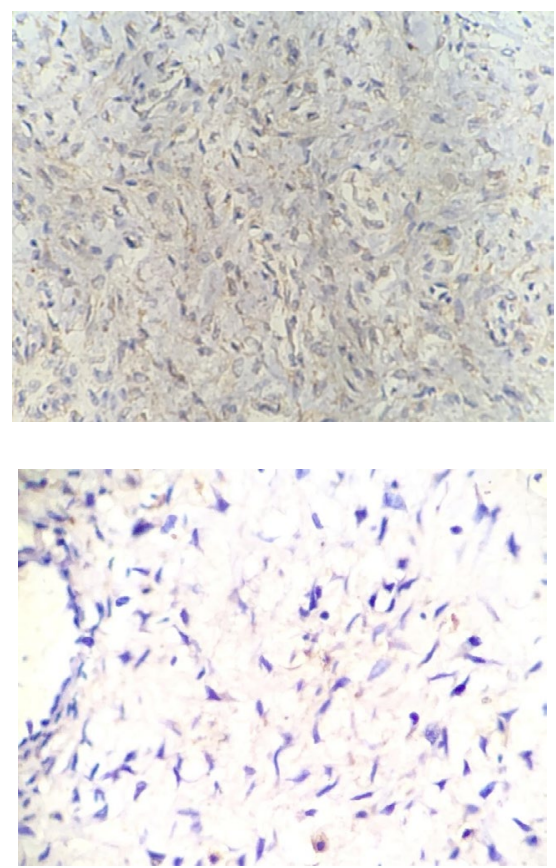

Figure 1. Image of MMP-9 and VEGF expression of nasopharyngeal angiofibroma with 400x magnification

In this study, the expression of MMP-9 and VEGF was not significantly correlated $(\mathrm{p}<0.099)$ (Table 3).

Prior to this study, there was no research on the correlation of MMP-9 and VEGF towards NA. Nevertheless, the study by Gao et al. ${ }^{14}$ on gastric cancer had shown that the MMP-9 and VEGF expression had no significant correlation. Other research reported a positive correlation between MMP9 and VEGF towards benign supratentorial meningioma cases. ${ }^{5}$

Matrix metalloproteinase (MMP) consisted of at least 5 groups based on structure and substrate's specificities. In general, MMP has the ability to degrade 
extracellular matrix (ECM) in the beginning of tumor's early formation. But, MMP-9 activity was not always pro-angiogenic. Some MMP is also able to form angiogenesis inhibitor so it could reduce VEGF secretion. ${ }^{8}$ Direct correlation between MMP in general, MMP-9 activation and VEGF level towards nasopharyngeal angiofibroma still need to be proven.

The conclusion was that VEGF expression had a correlation with NA clinical stage. Anti-VEGF need to be further studied as an alternative therapy for NA.

\section{REFERENCE}

1. Liu ZF, Wang DH, Sun XC, Wang JJ, Hu L, Li $\mathrm{H}$, et al. The site of origin and expansive routes of juvenile nasopharyngeal angiofibroma (JNA). Int J Pediatr Otorhinolaryngol. 2011; 75(9): 1088-92.

2. Safadi A, Schreiber A, Fliss DM, Nicolai P. Juvenile angiofibroma: current management strategies. J Neurosurg B. 2018; 79(1): $21-30$.

3. Duerr S, Wendler O, Aigner T, Karosi S, Schick B. Metalloproteinases in juvenile angiofibroma - a collagen rich tumor. Hum Pathol. 2008; 39: 259-68.

4. Mazlumoglu MR. Biomolecular analysis of juvenile nasopharyngeal angiofibroma. J Mol Genet Med. 2017; 11:4.

5. Iwado E, Ichikawa T, Kosaka H, Otsuka S, Kambara H, Tamiya T, et al. Role of VEGF and matrix metalloproteinase-9 in peritumoral brain edema associated with supratentorial benign meningiomas. Neuropathology. 2012; 32(6): 638-46.

6. Sun X, Guo L, Wang J, Wang H, Liu Z, Liu J, et al. Prognostic value of matrix metalloproteinase 9 expression in patients with juvenile nasopharyngeal angiofibroma: Tissue microarray analysis. Int J Pediatr Otorhinolaryngol. 2014; 78: 1232-38.

7. Vilen ST, Salo T, Sorsa T, Nyberg P.Fluctuating roles of matrix metalloproteinase-9 in oralsquamous cell carcinoma. Sci World J. 2013; Art ID 920595, 11 pages.
8. Moss LS, Taubman SJ, Stevenson WS. Matrix metalloproteinases changing roles in tumor progression and metastasis. Am J Pathol. 2012; 181 (6): 1895-9.

9. Nonogaki S, Campos HG, Butugan O, Soares FA, Mangone FR, Torloni H, et al. Markers of vascular differentiation, proliferation and tissue remodelling in juvenile nasopharyngeal angiofibromas. Exp Ther Med. 2010; 1: 921-6.

10. Pandey P, Mishra A, Tripathi AM, Verma V, Trivedi R, Singh HP, et al. Current molecular profile of juvenile nasopharyngeal angiofibroma: first comprehensive study from India. Laryngoscope. 2016; 127(3): E100-16.

11. Zhang M, Sun X, Yu H, Hu L, Wang D. Biological distinctions between juvenile nasopharyngeal angiofibroma and vascular malformation: An immunohistochemical study. Acta Histochem. 2011; 113: 626-630.

12. Liu Z, Wang J, Wang H, Wang D, Hu L, Liu Q. Hormonal receptors and vascular endothelial growth factor in juvenile nasopharyngeal angiofibroma: immunohistochemical and tissue microarray analysis. Acta Otolaryngol. 2015; 135(1): 51-7.

13. Hota A, Sarkar C, Gupta SD, Kumar R, Bhalla AS, Thakar A. Expression of vascular endothelial growth factor in Juvenile Angiofibroma. Int J Pediatr Otorhinolaryngol. 2015; 79(6): 900-2.

14. Gao H, Lan X, Li S, Xue Y. Relationships of MMP-9, E-cadherin, and VEGF expression with clinicopathological features and response to chemosensitivity in gastric cancer. Tumor Biol. 2017; 39(5): 1-7. 